\title{
二,三の高マンガン鋼の耐摩耗特性についで*
}

\author{
中 山正大** 財 満 鎮 雄*** 斎 藤大八 八*** $^{* * *}$
}

\section{On the Wear Resisting Property of Some High Manganese Steels}

by

\author{
Masamichi Nakayama, Shigeo Zaima and Daihachi Saito \\ (Nippon Casting Co., Ltd.) (Yamanashi Ùniversity) (Aichi Mechanical Industry Co., Ltd.)
}

Following the tests reported previously, the abrasion tests on high manganese steels of various components were conducted by means of a tube-mill type abrasion tester.

The results are summarized as follows:

(1) As to the effect of heat treatment on the wear resisting property of the ordinary high manganese steel, a good result is obtained in the case of $250^{\circ} \mathrm{C}$ tempering after quenched into water (even though there is not so much difference as compared with quenched ones), and the characteristics become worse when the tempering temperature rises to $650^{\circ} \mathrm{C}$.

(2) The wear resisting property is adversely affected by adding the silicon content in the ordinary high manganese steel.

(3) And also adding of chromium content is no good for the wear resisting property.

(4) The special manufactured high manganese steel shows excellent wear resistance notwithstanding its chemical composition which is not so different from that of ordinary high manganese steel.

(5) The result reported in the previous report, that the steel of large grain size is inferior to the steel of small grain size in the wear resisting property, is applied in this case.

(6) The relation between the wearing time and the amount of wear may be formularized experimentally as the formula (1), and in this case the constants in the formula show nearly constant values regardless of the quality of each material.

(7) The relation between the wearing time and the hardness is closely connected. The formula (2), and the constants in the formula are nearly equal in each material, and agree with the previous result that the increase of hardness with wearing time is very remarkable as compared with the carbon steel.

(Received Jul. 9, 1959)

\section{1. ま え}

従来から, 炭素 $0 \cdot 8 \sim 1 \cdot 3 \%$, マンガン 10〜14\%を 含む高マンガン鋼はいわゆる水じん法を施せば，強じ んにして摩耗に耐え, かつ衝撃に対する抵抗も大きく なるといわれ, 土木機械, 鉣山機械などのように強度 を要し耐摩耗性を必要とするものによく使用されてい る。しかし，他の材料における場合と同様にその耐摩 耗性の実態を充分に把握することは非常に困難であり， その大さな原因の一つとしては, 実施された摩耗試験

* 原稿受付 昭和 34 年 7 月 9 日, 当協会第 8 期総会講演会飞て偝 演 (昭34.5)

*** 日本鋳造株式会社川崎工場

**** 正員 山梨大学工学部

***** 愛知機械工業怢式会社
の結果がただちにすべての場合に適用できないことが ある．研削加工のさいにはこの材料の強じんさと加工 困難なことに手をやき，グラインダーの消耗はとくに はなはだしいことはしばしば経験するところであるが, 最近の報告では転動にすべりを伴なった摩耗試験にお いて(とくにレールを対象として)高マンガン鋼はかな りの摩耗量が認められている。したがって, 高マンガ ン鋼の耐摩耗特性を検討するに充分な摩耗試験の諸条 件を確立するためには, さらに今後の研究に待つべき ことと思われる。

著者らはさきにチューブミル型式による摩耗試験機 を試作し，その套部の裏張りに試料を用いて鋼球と珪 砂を入れて回転し, 使用条件に近い方法で種々の成分 
の普通高マンガン鋼の摩耗試験を実施した. その結果, 普通の炭素鋼と比較して耐摩耗特性の概要を知ること ができ，製造のさいのいちおうの目安を得た。

ここに報告するものは, 焼入れ(水じん)した普通高 マンガン鋼を焼戻した場合の耐摩耗性，クロームを添 加したクロームマンガン鋼およびその含有成分は，普 通高マンガン鋼と比べて大差ないが，その溶解法に特 殊な考虑を払った特殊溶解高マンガン鋼などの耐摩耗 性について，引続いて行なった実験結果についてであ る.

\section{2. 試料および実験条件}

実験に供した試料は前報と同様に，Fig. 1 の形状に

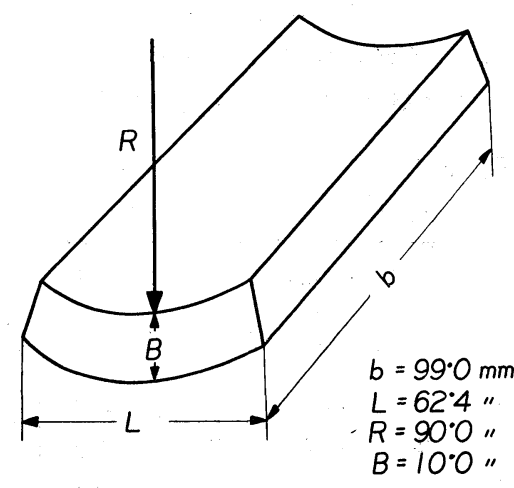

Fig. 1 The specimen

Table 1 The chemical compositions of specimens (1)

\begin{tabular}{|c|c|c|c|c|c|c|c|c|}
\hline \multirow{2}{*}{ Specimen } & \multirow{2}{*}{ Material } & \multicolumn{6}{|c|}{ Compositions } & \multirow{2}{*}{ Remarks } \\
\hline & & $\mathrm{C}(\%)$ & $\mathrm{Si}(\%)$ & $\operatorname{Mn}(\%)$ & $\mathrm{P}(\%)$ & $\mathrm{S}(\%)$ & $\mathrm{Cr}(\%)$ & \\
\hline No. 1 & \multirow{9}{*}{$\begin{array}{c}\text { Ordinary high } \\
\text { manganese } \\
\text { steel }\end{array}$} & & & & & & & $1050^{\circ} \mathrm{C}$ quenched (water) \\
\hline No. 2 & & $1 \cdot 00$ & $0 \cdot 31$ & $12 \cdot 08$ & 0.048 & 0.008 & $\longrightarrow$ & $250^{\circ} \mathrm{C}$ tempered \\
\hline No. 3 & & & & & & & & $650^{\circ} \mathrm{C}$ tempered \\
\hline No. 4 & & & & & & & & $1050^{\circ} \mathrm{C}$ quenched (water) \\
\hline No. 5 & & $1 \cdot 02$ & $0 \cdot 30$ & $13 \cdot 96$ & 0.039 & 0.013 & - & $250^{\circ} \mathrm{C}$ tempered \\
\hline No. 6 & & & & & & & & $650^{\circ} \mathrm{C}$ tempered \\
\hline No. 7 & & & & & & & & $1050^{\circ} \mathrm{C}$ quenched (water) \\
\hline No. 8 & & $1 \cdot 02$ & $0 \cdot 29$ & $13 \cdot 33$ & 0.052 & 0.009 & - & $250^{\circ} \mathrm{C}$ tempered \\
\hline No. 9 & & & & & & & & $650^{\circ} \mathrm{C}$ tempered \\
\hline
\end{tabular}

Table 2 The chemical compositions of specimens (2)

\begin{tabular}{|c|c|c|c|c|c|c|c|c|}
\hline Specimen & Materials & $\mathrm{C}(\%)$ & $\mathrm{Si}(\%)$ & $\operatorname{Mn}(\%)$ & $\mathrm{P}(\%)$ & $\mathrm{S}(\%)$ & $\operatorname{Cr}(\%)$ & Remarks \\
\hline $\begin{array}{l}\text { No. } 10 \\
\text { No. } 11 \\
\text { No. } 12 \\
\text { No. } 13 \\
\text { No. } 14 \\
\text { No. } 15\end{array}$ & $\begin{array}{l}\text { Chrome } \\
\text { manganese } \\
\text { steel }\end{array}$ & $1 \cdot 09$ & $1 \cdot 30$ & $13 \cdot 55$ & 0.030 & 0.004 & $1 \cdot 760$ & $1050^{\circ} \mathrm{C}$ quenched (water) \\
\hline $\begin{array}{l}\text { No. } 16 \\
\text { No. } 17 \\
\text { No. } 18\end{array}$ & $\begin{array}{l}\text { Ordinary high } \\
\text { manganese } \\
\text { steel } \\
\text { (high silicon) }\end{array}$ & 0.97 & $1 \cdot 42$ & $13 \cdot 09$ & 0.028 & 0.008 & - & $1050^{\circ} \mathrm{C}$ quenched (water) \\
\hline $\begin{array}{l}\text { No. } 19 \\
\text { No. } 20 \\
\text { No. } 21 \\
\text { No. } 22 \\
\text { No. } 23 \\
\text { No. } 24 \\
\text { No. } 25 \\
\text { No. } 26 \\
\text { No. } 27\end{array}$ & $\begin{array}{c}\text { Specially } \\
\text { manufactured } \\
\text { high manga- } \\
\text { nese steel }\end{array}$ & $1 \cdot 04$ & 0.54 & $12 \cdot 25$ & 0.048 & 0.009 & 0.030 & $1050^{\circ} \mathrm{C}$ quenched (water) \\
\hline
\end{tabular}


それぞれ 1 個ずつ鋳込んだ Table 1 および Table $2 に$ 示すような成分の高マンガン鋼である。すなわち, 普 通高マンガン鋼老 $1050^{\circ} \mathrm{C}$ (1 hr 保持)より水焼入れ(20

Table 3 The mechanical properties of specimens

\begin{tabular}{l|c|c|c|c|c}
\hline Speci- & $\begin{array}{r}\text { Tensile } \\
\text { strength } \\
\text { men }\end{array}$ & $\begin{array}{c}\text { Elonga- } \\
\text { tion } \\
\left(\mathrm{kg} / \mathrm{mm}^{2}\right)\end{array}$ & \multicolumn{3}{|c}{ Hardness } \\
\cline { 4 - 6 } & $\%$ & $\begin{array}{c}\text { Brinell } \\
\text { hardness }\end{array}$ & $\begin{array}{c}\text { Rockwel1 } \\
\text { hardness }\end{array}$ & $\begin{array}{c}\text { Shore } \\
\text { hardness }\end{array}$ \\
\hline No. 1 & $93 \cdot 9$ & $64 \cdot 0$ & 179 & $44 \cdot 3$ & 37 \\
No. 4 & $93 \cdot 5$ & $54 \cdot 0$ & 191 & $37 \cdot 2$ & 34 \\
No. 7 & $91 \cdot 3$ & $55 \cdot 0$ & 207 & $37 \cdot 1$ & 35 \\
No. 10 & $95 \cdot 1$ & $47 \cdot 8$ & 211 & $45 \cdot 1$ & 38 \\
No. 16 & $91 \cdot 6$ & $53 \cdot 0$ & 190 & $41 \cdot 0$ & 33 \\
No. 19 & $91 \cdot 0$ & $54 \cdot 6$ & 177 & $40 \cdot 1$ & 35 \\
\hline
\end{tabular}

'C)した No. 1, No. 4 および No. 7 と, 熱処理効 果をみるためそれらの試料を $250^{\circ} \mathrm{C}(1 \mathrm{hr})$ に暁戻した No. 2, No. 5 および No. $8,650^{\circ} \mathrm{C}(1 \mathrm{hr})$ に焼戻し た No. 3, No. 6 および No. 9 について検討し, さ らにこれまで検討してきた普通高マンガン鋼は珪素含 有量が $0.2 \sim 0.5 \%$ 程度であったので, 珪素の含有効 果をみるため炭素およびマンガン量はこれまでと大差 ないが, 珪素が $1.4 \%$ と多量に含んだ高マンガン鋼を 同様に $1050^{\circ} \mathrm{C}$ 上り水焼入れした試料 No. 16〜No. 18, クロームの添加効果をみるため $1 \cdot 76 \% \mathrm{Cr}$ を加えたク ロームマンガン鋼を $1050^{\circ} \mathrm{C}$ より水巃入れした試料 No. 10〜No.15, およびマンガン, 炭素, 珪素そのほ か含有成分は普通高マンガン鋼と同様な成分をもつが， その製法，とくに溶解のさい特別な処理をした特殊溶 解高マンガ:鋼を $1050^{\circ} \mathrm{C} よ り$ 水焼入れした試料 No.

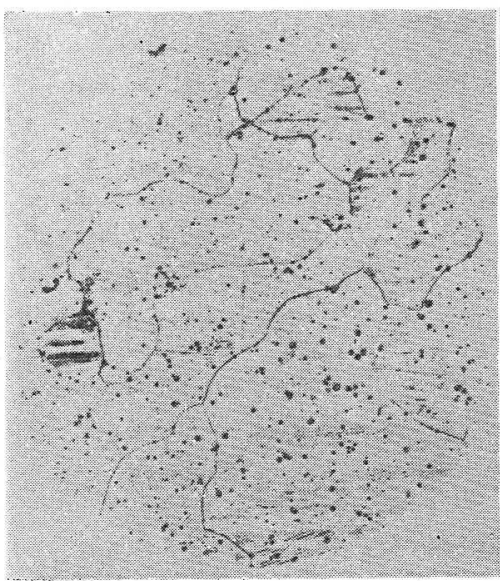

No. 1

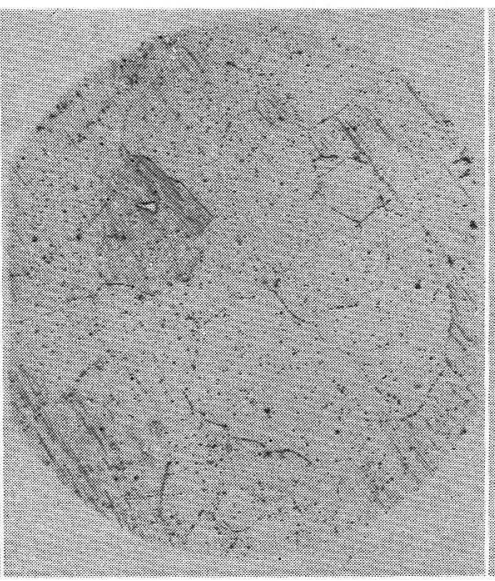

No. 2

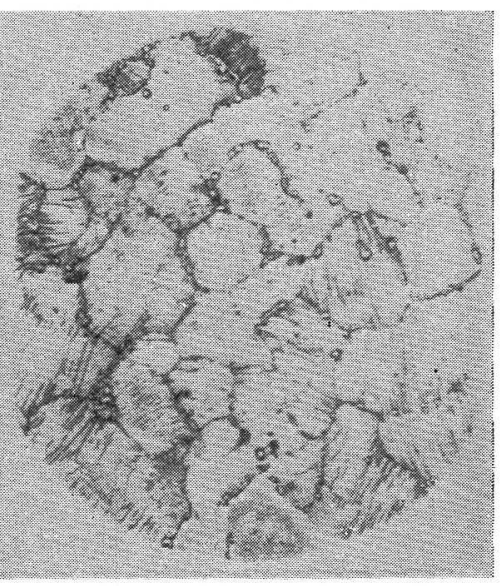

No. 3

Photo. 1 Ordinary high manganese steel, specimen No. 1 (as water quenched), No. $2\left(250^{\circ} \mathrm{C}\right.$ tempered) and No. $3\left(650^{\circ} \mathrm{C}\right.$ tempered $)(\times 100 \times 2 / 3)$

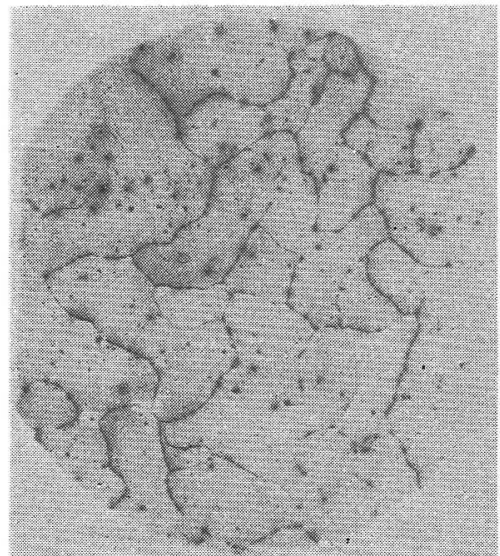

No. 10

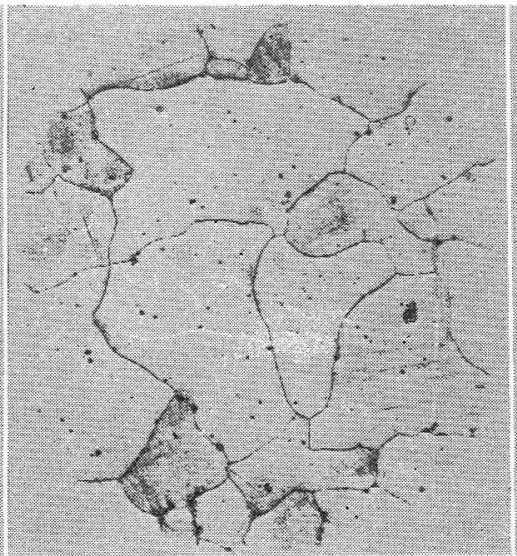

No. 17

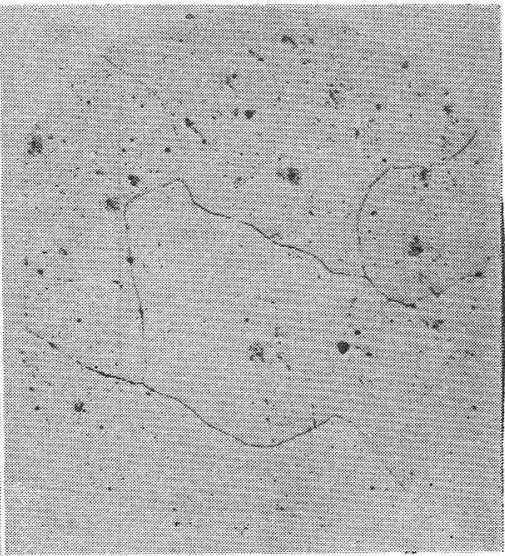

No. 19

Photo. 2 Chrome manganese steel, specimen No. 10 (as water quenched), ordinary high manganese steel (high silicon), No. 17 (as water quenched) and specially manufactured high manganese steel, No. 19 (as water quenched) $(\times 100 \times 2 / 3)$ 
19〜No. 27 について特泩を求めた.

これらの試料の二, 三の機械的性質を示せば Table 3 のようになる。表よりみれば, No. 1, No. 4, No. 7 , (以上普通高マンガン鋼), No. 16 (高珪素普通高マ ンガン鋼) および No. 19 (特殊溶解高マンガン鋼) で は引張強さ, 伸びあるいは硬さについても大差ないが, No. 10 (クロームマンガン鋼) では引張強さおよび硬 さは前者に比べていくぶん高く，伸びは低いことがわ かる。

顕微鏡組織 $(\times 100 \times 2 / 3)$ を示せば Photo. 1 は普通 高マンガン鋼の熱処理による変化を示すが, No. 2 で は焼戻しの影響は明膫ではなく；No. 3 では焼戻しに よる第 2 相の析出が認められている. Photo. 2 は No. 10, No. 17 および No. 19 を示すが, 成分および溶解 法の違いによる組織の差はみることができなかった。

これらの試料を 9 枚と比較のための標準試験片とし て同型の $0 \cdot 14 \%$ 炭素鋼片（前報で用いたものと同一成 分で, $880^{\circ} \mathrm{C}$ 水焼入れすれば試験前のロックウエル硬 さ $H_{R B}$ が試料とほぼ同じであるために採用した）を 1 枚入れて, 前報で示したチューブミル型式の摩耗試 験機の套部の襄張りとし，その中に軸受鋼球（約 $2 \cdot 8$ $\mathrm{kg}$ )を 10 個，珪砂を $500 \mathrm{gr} / 5 \mathrm{hr}$ の割合で入れて 20 $\mathrm{rpm}$ の回転を与え, 回転と打撃による摩耗試験を行な った。

\section{3. 普通高マンガン鋼}

普通高マンガン鋼の熱処理による耐摩耗性の变化は Fig. 2 のようである. 図よりみれば， $250^{\circ} \mathrm{C}$ の焼戻 したもの (No. 2, No. 5, No. 8) では焼入れのままの もの (No. 1, No. 4, No. 7) より多少耐摩耗性はよく なる傾向にあったが大差なく，650 $\mathrm{C}$ 焼戻し(No. 3, No. 6, No. 9) では耐摩耗性は悪くなることがわかる. 前報で知った試験時間の経過とともに硬さ（ロックウ エル硬さ $H_{R B}$ およびショアー硬さ $H_{S}$ で検討した） が標準炭素鋼に比べて急激にかつ高く上年して飽和值 に近づいた特性と同傾向に現われ，また，オーステナ イト粒度を調べれば, 後述の Table 4 などのように No. 1 は 2 , No. 4 は 3 , No. 7 は 5 であり, 初期 粒度の小さいほうが耐摩耗性の良好であった前報の結 果に一致した。

つぎに，珪素の含有効果をみるために行なった結果 はFig. 3 のようになり, Table 2 よりみて機械的性質 は普通高マンガン鋼に比べほとんど大差ないにもかか わらず，いずれも標準炭素鋼あるいは Fig. 2 の普通高 マンガン鋼に比べ劣り, 珪素は耐摩耗性に悪い効果を 示すことがわかった. また, 結晶粒度からみればこの 場合も粗粒が劣ることは Table 4 にもみられるとお りであり, 硬さ変化も前述の場合と同傾向の特性をと った。

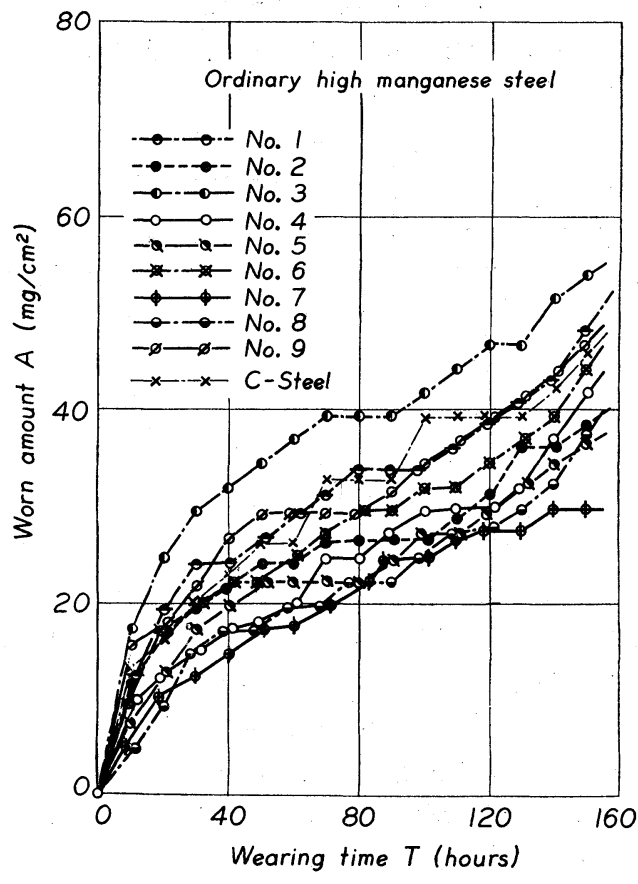

Fig. 2 The relation between the wearing time $T$ and the worn amount $A$ in the case of the ordinary high manganese steel

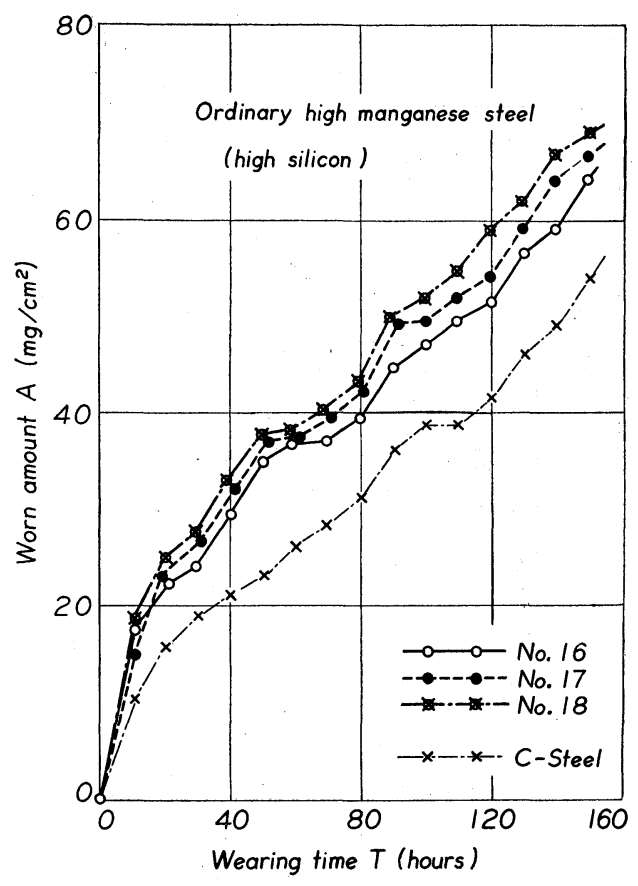

Fig. 3 The relation between the wearing time $T$ and the worn amount $A$ in the case of the ordinary high manganese steel (high silicon) 


\section{4. クロームマンガン鋼}

クロームマンガン鋼について同樣な実験を行なった 結果は Fig. 4 のようになり, Table 3 からみれば機 械的強度はかなりすぐれているようであるが，この場 合も普通高マンガン鋼あるいは標準炭素鋼に比べて耐 摩耗特性は非常に劣っている。. しかし, 結晶粒度は, Table 4 にみるように 3〜5.5 の範囲でいずれも比較 的微細なもののみであるためか, 明瞭な粒度の差は認 められなかった。

摩耗時間 $T$ の経過による試験面のロックウエル硬さ (Bスケール) $H_{R B}$, およびショア一硬さ $H_{S}$ の変化 の一例老示せば Fig. 5 のようになり, 標準炭素鋼と は異なった高マンガン鋼特有の摩耗時間の経過に伴な い硬さの急上犁特性をとるが，硬さの飽和值にいたる までの時間が他の場合に比へていくぶん長くかかるよ うである(とくに $H_{S}$ にその傾向が強い).

\section{5. 特殊溶解高マンガン鋼}

摩耗時間 $T$ の経過と摩耗量 $A$ の関係は Fig. 6 のよ うになり，普通高マンガン鋼に比べて非常にすぐれた 耐摩耗特性を示すことがわかり，この場合も初期粒度 の細かい場合が粗粒の場合に比べて摩耗量が少ないこ とがみられる. 化学成分からみれば普通高マンガン鋼

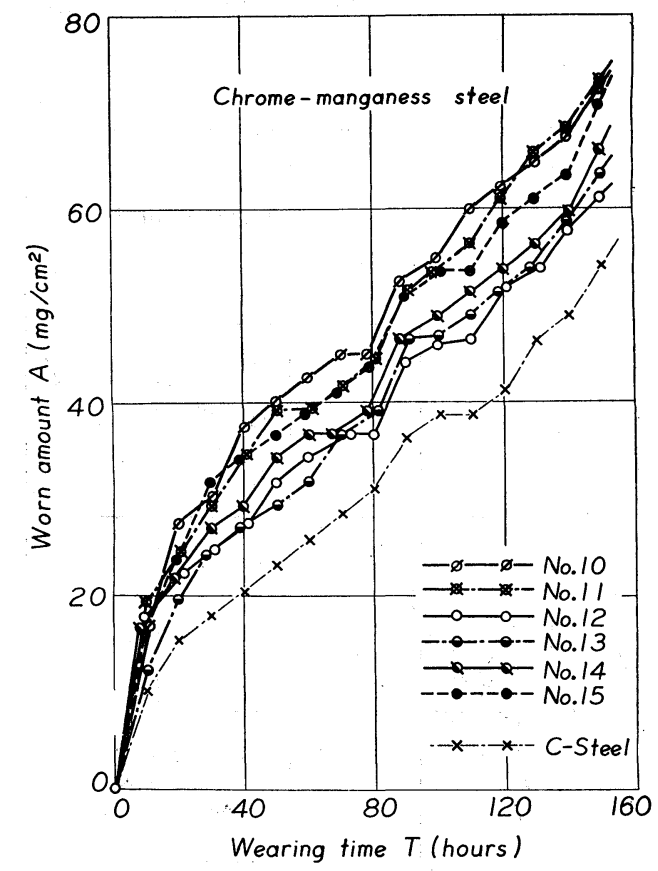

Fig. 4 The relation between the wearing time $T$ and the worn amount $A$ in the case of the chrome-manganese steel

* 鉱石处理に実際使用した結果では，硕い鉱石の場合クロームを含 有しないほうが摩耗面の状態は良好であったが，此較的軟い鉱石の 場合クロームを含有したほうが晋通高マンガン制より良好となった。 今後の検討を要するところと思 5

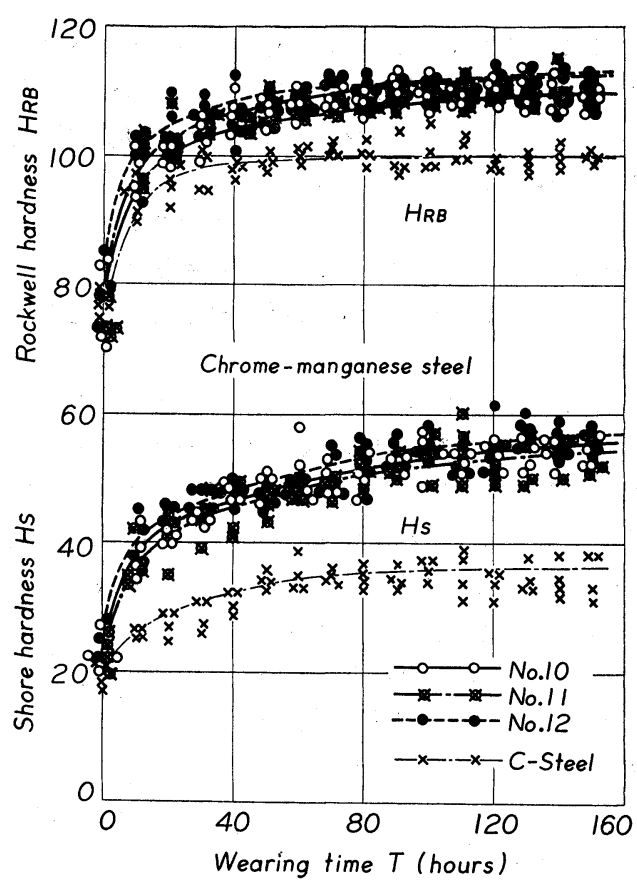

Fig. 5 The change of hardness (Rockwell hardness $H_{R B}$ and Shore hardness $H_{S}$ ) in the case of the chrome-manganese steel

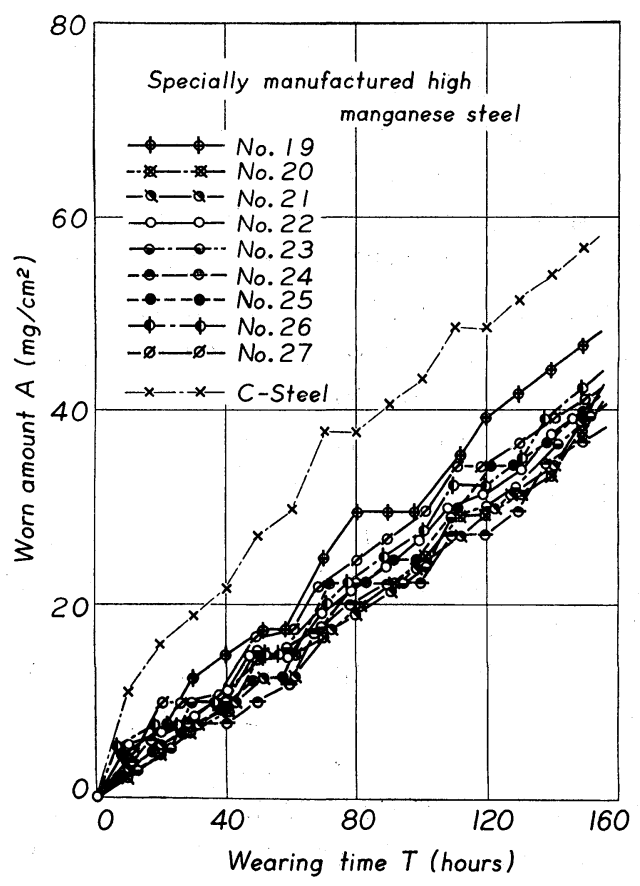

Fig. 6 The relation between the wearing time $T$ and the worn amount $A$ in the case of the specially manufactured high manganese steel 
とほとんど大差ないにもかかわらず，製造のさいとく に特殊溶解処理によってこのように特泩にいちじるし い差ができたことがわかる。

また, 摩耗時間 $T$ と硬さ $H_{R B}$ および $H_{S}$ の変化 との関係は，たとえば Fig. 7 .のように高マンガン鋼 特有の硬さの急上昇をとるが, 前述の普通高マンガン

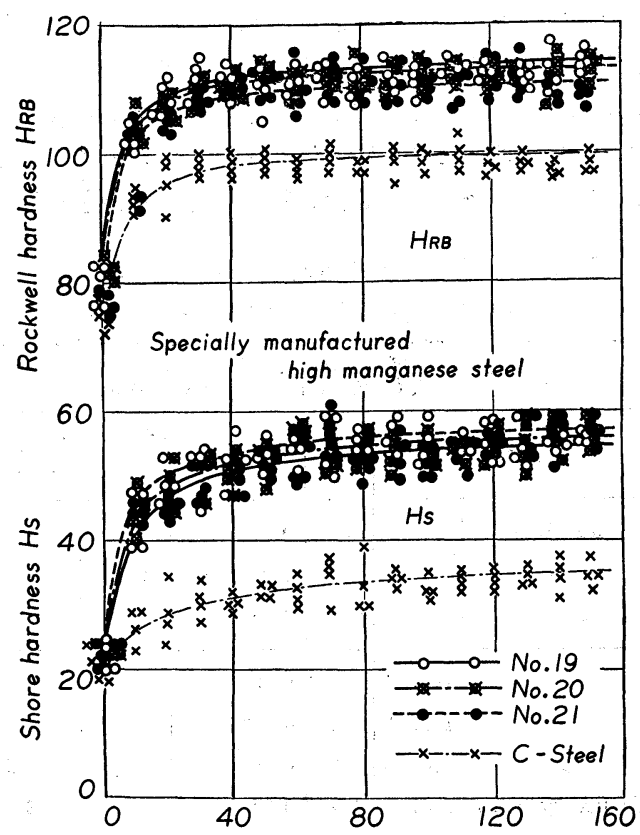

Fig. 7 The change of hardness (Rockwell hardness $H_{R B}$ and Shore hardness $H_{S}$ ) in the case of the specially manufactured high manganese steel

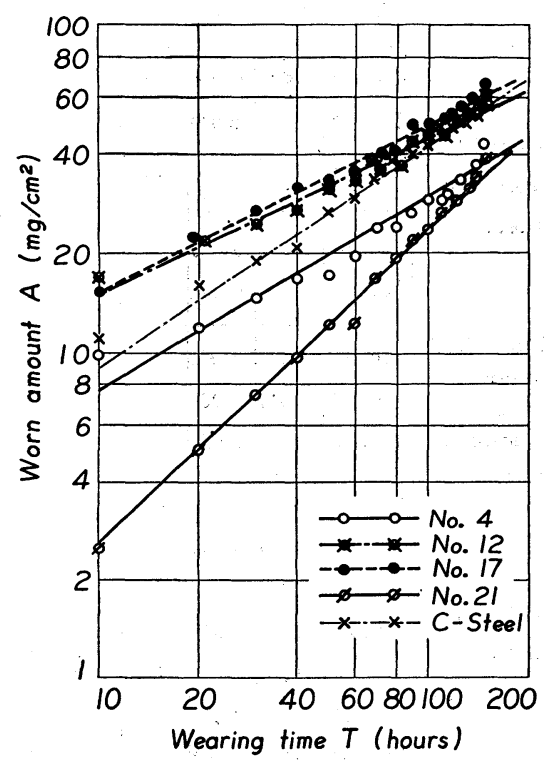

Fig. 8 Example of the logarithmic relation between the wearing time $T$ and the worn amount $A$
鋼およびクロームマンガン鋼に比べて硬さの上年飽和 は急激でかつ早かったようである。

\section{6. 結 果 の 検 討}

前報の結果より判断すれば, 普通高マンガン鋼は摩 耗の初期に摩耗量はかなりはげしいが, 時間の経過に より硬さが急上䄯して, 飽和值に近づくにつれて摩耗 量も定常化してき, また, 八木氏の結果によっても加 工硬化の充分でない時期における摩耗量の多いこと が認められたことから, 高マンがン鋼ではとくに加工 によって硬さが急上昇して飽和するまでの初期摩耗が とくに重要な意味をもつことが考えられる。この場合 についてもこのことはだいたい正しいとみてさしつか

Table 4 The constants $a$ and $b$ in Eq. (1)

\begin{tabular}{|c|c|c|c|c|c|c|}
\hline \multicolumn{7}{|c|}{$A=a \cdot T^{b} \quad\left(\begin{array}{l}A=\text { Worn amount in } \mathrm{mg} / \mathrm{cm}^{2} \\
T=\text { Wearing time in hour }\end{array}\right)$} \\
\hline \multicolumn{2}{|l|}{ Specimen } & \multirow{2}{*}{$\begin{array}{c}a \\
11: 8 \\
9 \cdot 7 \\
9: 5\end{array}$} & \multirow{2}{*}{$\frac{|c|}{0}\left|\begin{array}{c}0.49 \\
0.58 \\
0.66\end{array}\right|$} & \multicolumn{2}{|c|}{ Mean } & $\begin{array}{l}\text { Grain } \\
\text { size }\end{array}$ \\
\hline $\begin{array}{l}\text { Standard } \\
\text { carbon } \\
\text { steel }\end{array}$ & & & & $10 \cdot 3$ & 0.58 & \\
\hline $\begin{array}{c}\text { Ordinary high } \\
\text { manganese } \\
\text { steel }\end{array}$ & $\begin{array}{ll}\text { No. } & 1 \\
\text { No. } & 2 \\
\text { No. } & 3 \\
\text { No. } & 4 \\
\text { No. } & 5 \\
\text { No. } 6 \\
\text { No. } 7 \\
\text { No. } 8 \\
\text { No. } 9\end{array}$ & $\begin{array}{r}13 \cdot 3 \\
12 \cdot 5 \\
19 \cdot 3 \\
9 \cdot 2 \\
8 \cdot 2 \\
16 \cdot 2 \\
5 \cdot 7 \\
5 \cdot 9 \\
13 \cdot 2\end{array}$ & $\begin{array}{l}0.43 \\
0.37 \\
0.36 \\
0.48 \\
0.52 \\
0.49 \\
0.63 \\
0.65 \\
0.43\end{array}$ & $9 \cdot 4$ & 0.51 & $\begin{array}{c}3 \\
4 \\
3.5 \\
2 \\
3 \\
3.5 \\
-2 \\
-1 \\
2.5\end{array}$ \\
\hline $\begin{array}{c}\text { Chrome } \\
\text { manganese } \\
\text { steel }\end{array}$ & $\begin{array}{l}\text { No. } 10 \\
\text { No. } 11 \\
\text { No. } 12 \\
\text { No. } 13 \\
\text { No. } 14 \\
\text { No. } 15\end{array}$ & $\begin{array}{l}17 \cdot 3 \\
17 \cdot 8 \\
15 \cdot 2 \\
12 \cdot 4 \\
15 \cdot 5 \\
13 \cdot 6\end{array}$ & $\begin{array}{l}0.51 \\
0.48 \\
0.48 \\
0.57 \\
0.48 \\
0.61\end{array}$ & $15 \cdot 3$ & 0.52 & $\begin{array}{l}5 \cdot 5 \\
5 \cdot 5 \\
3 \\
3 \\
3 \cdot 5 \\
4\end{array}$ \\
\hline $\begin{array}{c}\text { Ordinary high } \\
\text { manganese } \\
\text { steel } \\
\text { (high silicon) }\end{array}$ & $\begin{array}{l}\text { No. } 16 \\
\text { No. } 17 \\
\text { No. } 18\end{array}$ & $\begin{array}{c}16 \cdot 5 \\
14 \cdot 9 \\
17 \cdot 8\end{array}$ & $\begin{array}{l}0.44 \\
0.52 \\
0.49\end{array}$ & $16 \cdot 4$ & $0 \cdot 48$ & $\begin{array}{l}5 \\
3 \\
2\end{array}$ \\
\hline $\begin{array}{c}\text { Specially } \\
\text { manufactured } \\
\text { high manga- } \\
\text { nese steel }\end{array}$ & $\begin{array}{l}\text { No. } 19 \\
\text { No. } 20 \\
\text { No. } 21 \\
\text { No. } 22 \\
\text { No. } 23 \\
\text { No. } 24 \\
\text { No. } 25 \\
\text { No. } 26 \\
\text { No. } 27\end{array}$ & $\begin{array}{l}4 \cdot 2 \\
2 \cdot 4 \\
2 \cdot 6 \\
5 \cdot 2 \\
3 \cdot 4 \\
2 \cdot 4 \\
3 \cdot 8 \\
5 \cdot 4 \\
4 \cdot 4\end{array}$ & $\begin{array}{l}0.88 \\
1.00 \\
0.96 \\
0.68 \\
0.86 \\
0.98 \\
0.83 \\
0.71 \\
0.77\end{array}$ & $3 \cdot 8$ & $0 \cdot 86$ & $\begin{array}{l}2 \cdot 5 \\
2 \\
3 \\
2 \\
3 \cdot 5 \\
4 \\
3 \\
5 \\
5\end{array}$ \\
\hline
\end{tabular}


えないようで,ここでは主として初期摩耗について検 討を加えた。

前述の摩耗特性曲線を摩耗時間 $T$ と摩耗量 $A$ の両 対数線図にとれば(前記各試料群より各一例をとれば), たとえば Fig. 8 のようになり直線的関係が得られる. すなわち，材料による定数を $a ， b$ とすれば定性的に

$$
A=a \cdot T^{b}
$$

が成立する。これら $a, b$ の定数を最小自乗法によっ て各試料別に求めてみれば Table 4 を得る。 それぞ れ同一試料群では $a, b$ ともにそれぞれほぼ等しい值 をとることがわかり，したがって，その平均値も併記 したａａ值の大きい高珪素高マンガン鋼，クローム マンガン鋼では初期摩耗がはなはだしく，aのとくに 小さい特殊溶解高マンガン鋼では初期摩耗の少ないこ とが明らかになっている．普通高マンガン鋼の熱処理 効果も， $250^{\circ} \mathrm{C}$ 焼戻しでは焼入れのままのものよりや や耐摩耗性は良い上うであるが， $650^{\circ} \mathrm{C}$ 䍒戻しではは なはだ劣ることも表か.ら定量的にも明膫に知ることが できる。

また，摩耗初期における摩耗時間 $T$ と硬さ $H$ を両 対数線図にまとめると，たとえば Fig. 9 のようにな り，すべての場合に $c, d$ を材料による定数とすれば 定性的に

$$
H=c \cdot T^{d}
$$

が成立する(ロックウエル硬さ $H_{R B}$ およびショアー 硬さ $H_{S}$ について). 各試料について定数 $c, d$ を最小

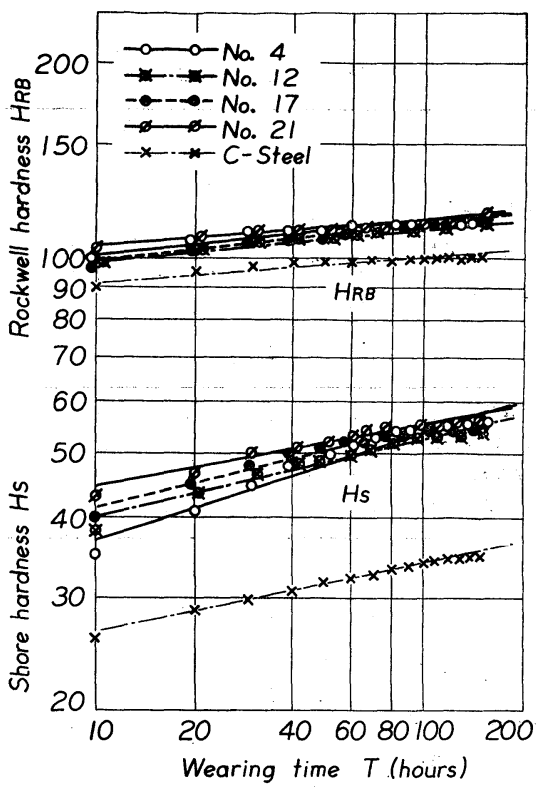

Fig. 9 Example of the logarithmic relation between the wearing time $T$ and the hardness (Rockwell hardness $H_{R B}$ and Shore hardness $H_{S}$ )
自乗法によってまとめれば，口ックウエル硬さ $H_{R B}$ の場合 Table 5 , ショア一硬さ $H_{S}$ の場合 Table 6 のようになる。それぞれ各試料群においてはほぼ等し い值をとり，cの值の大きいことはとくに初期におけ る硬さ上升のはなはだしいことを示す。

以上の結果より，この場合，硬さ曲線は各試料とも だいたい 150 時間経過すればそれぞれ飽和值に近くな るようであったので, 実験開始後 150 時間における各 試料についての初期硬さと上昇率の関係を求めれば, ロックゥェル硬さについては Fig. 10，ショア一硬さ については Fig. 11 を得た。初期硬さの低いものが全

Table 5 The constants $c$ and $d$ in Eq. (2)

\begin{tabular}{|c|c|c|c|c|c|c|}
\hline \multicolumn{7}{|c|}{$H_{R B}=c \cdot T^{d}\left(\begin{array}{l}H_{R B}=\text { Rockwell hardness } \\
T=\text { Wearing time in hour }\end{array}\right)$} \\
\hline \multirow{2}{*}{\multicolumn{2}{|c|}{ Specimen }} & \multirow{2}{*}{ c } & \multirow{2}{*}{ d } & \multicolumn{2}{|c|}{ Mean } & \multirow{2}{*}{$\begin{array}{l}\text { Grain } \\
\text { size }\end{array}$} \\
\hline & & & & $c$ & $d$ & \\
\hline $\begin{array}{l}\text { Standard } \\
\text { carbon } \\
\text { steel }\end{array}$ & & $\begin{array}{l}89 \cdot 5 \\
93 \cdot 7 \\
88 \cdot 7\end{array}$ & $\begin{array}{l}0.046 \\
0.021 \\
0.055\end{array}$ & $90 \cdot 7$ & 0.041 & \\
\hline $\begin{array}{c}\text { Ordinary high } \\
\text { manganese } \\
\text { steel }\end{array}$ & $\begin{array}{ll}\text { No. } & 1 \\
\text { No. } & 2 \\
\text { No. } & 3 \\
\text { No. } & 4 \\
\text { No. } & 5 \\
\text { No. } & 6 \\
\text { No. } & 7 \\
\text { No. } & 8 \\
\text { No. } & 9\end{array}$ & $\begin{array}{r}93 \cdot 8 \\
104 \cdot 7 \\
99 \cdot 8 \\
104 \cdot 7 \\
107 \cdot 4 \\
102 \cdot 6 \\
103 \cdot 5 \\
103 \cdot 5 \\
103 \cdot 5\end{array}$ & $\begin{array}{l}0.051 \\
0.032 \\
0.058 \\
0.0: 0 \\
0.036 \\
0.031 \\
0.032 \\
0.032 \\
0.032\end{array}$ & $100 \cdot 7$ & $\begin{array}{c}0.041 \\
\text { as } \\
\text { quench }\end{array}$ & $\begin{array}{l}3 \\
4 \\
3 \cdot 5 \\
2 \\
3 \\
3 \cdot 5 \\
-2 \\
-1 \\
2 \cdot 5\end{array}$ \\
\hline $\begin{array}{c}\text { Chrome } \\
\text { manganese } \\
\text { steel }\end{array}$ & $\begin{array}{l}\text { No. } 10 \\
\text { No. } 11 \\
\text { No. } 12 \\
\text { No. } 13 \\
\text { No. } 14 \\
\text { No. } 15\end{array}$ & $\begin{array}{c}97 \cdot 1 \\
89 \cdot 2 \\
101 \cdot 2 \\
98 \cdot 0 \\
102 \cdot 0 \\
100 \cdot 3\end{array}$ & $\begin{array}{l}0.071 \\
0.038 \\
0.029 \\
0.032 \\
0.030 \\
0.036\end{array}$ & $98 \cdot 1$ & 0.039 & $\begin{array}{l}5 \cdot 5 \\
5 \cdot 5 \\
3 \\
3 \\
3 \cdot 5 \\
4\end{array}$ \\
\hline $\begin{array}{l}\text { Ordinary high } \\
\text { manganese } \\
\text { steel } \\
\text { (high silicon) }\end{array}$ & $\begin{array}{l}\text { No. } 16 \\
\text { No. } 17 \\
\text { No. } 18\end{array}$ & $\begin{array}{l}99 \cdot 1 \\
98 \cdot 0 \\
98 \cdot 0\end{array}$ & $\begin{array}{l}0.046 \\
0.036 \\
0.029\end{array}$ & $98 \cdot 3$ & 0.037 & $\begin{array}{l}5 \\
3 \\
2\end{array}$ \\
\hline $\begin{array}{c}\text { Specially } \\
\text { manufactured } \\
\text { high manga- } \\
\text { nese steel }\end{array}$ & $\begin{array}{l}\text { No. } 19 \\
\text { No. } 20 \\
\text { No. } 21 \\
\text { No. } 22 \\
\text { No. } 23 \\
\text { No. } 24 \\
\text { No. } 25 \\
\text { No. } 26 \\
\text { No. } 27\end{array}$ & $\begin{array}{r}98 \cdot 0 \\
98 \cdot 0 \\
100 \cdot 0 \\
98 \cdot 0 \\
96 \cdot 4 \\
99 \cdot 1 \\
96 \cdot 6 \\
99 \cdot 8 \\
97 \cdot 5\end{array}$ & $\begin{array}{l}0.058 \\
0.058 \\
0.043 \\
0.058 \\
0.033 \\
0.053 \\
0.063 \\
0.046 \\
0.054\end{array}$ & $98: 0$ & $0.05 j$ & $\begin{array}{l}2 \cdot 5 \\
2 \\
3 \\
2 \\
3 \cdot 5 \\
4 \\
3 \\
5 \\
5\end{array}$ \\
\hline
\end{tabular}
in the case of Rockwell hardness 
般的にみて硬さ上抙率も高いようであるが，各材料之 も標準炭素鋼に比べ非常に大さな硬さ上升率を示すこ とは, 従来のオーステナイト鋼の特性と矛盾しなかっ た．図よりみるように，同一試料群ではほぼ等しい硬 さと上界率を示すことがわかるが，ロックウエル硬さ とショアー硬さでその傾向が異なった。すなわち，口 ックウエル硬さでみれば, 初期硬さは普通高マンガン 鋼がもっとも低く, クロームマンガン鋼はやや高く, 特殊溶解高マンガ:鋼はもっとも高く出て, しかも硬 さ上昇率は後者がもっとも少なく，普通高マンガン鋼 がもっとも多いようであったが（珪素添加の効果は顕

Table 6 The constants $c$ and $d$ in Eq. (2) in the case of Shore hardness

\begin{tabular}{|c|c|c|c|c|c|c|}
\hline \multicolumn{7}{|c|}{$H_{S}=c \cdot T^{d}\left(\begin{array}{l}H_{S}=\text { Shore hardness } \\
T=\text { Wearing time in hour }\end{array}\right)$} \\
\hline \multirow{2}{*}{\multicolumn{2}{|c|}{ Specimen }} & \multirow{2}{*}{ c } & \multirow{2}{*}{ d } & \multicolumn{2}{|c|}{ Mean } & \multirow{2}{*}{$\begin{array}{l}\text { Grain } \\
\text { size }\end{array}$} \\
\hline & & & & c & $\mathrm{d}$ & \\
\hline $\begin{array}{c}\text { Standard } \\
\text { carbon } \\
\text { steel }\end{array}$ & & $\begin{array}{l}31 \cdot 0 \\
25 \cdot 5 \\
30 \cdot 8\end{array}$ & $\begin{array}{l}0 \cdot 26 \\
0 \cdot 13 \\
0 \cdot 23\end{array}$ & $29 \cdot 1$ & 0.21 & $\because$ \\
\hline $\begin{array}{l}\text { Ordinary high } \\
\text { manganese } \\
\text { steel }\end{array}$ & $\begin{array}{ll}\text { No. } & 1 \\
\text { No. } & 2 \\
\text { No. } & 3 \\
\text { No. } & 4 \\
\text { No. } & 5 \\
\text { No. } 6 \\
\text { No. } 7 \\
\text { No. } 8 \\
\text { No. } 9\end{array}$ & $\begin{array}{l}41 \cdot 1 \\
43 \cdot 3 \\
47 \cdot 3 \\
35 \cdot 3 \\
41 \cdot 9 \\
36 \cdot 1 \\
34 \cdot 4 \\
38 \cdot 6 \\
37 \cdot 5\end{array}$ & $\begin{array}{l}0 \cdot 13 \\
0 \cdot 10 \\
0 \cdot 05 \\
0 \cdot 17 \\
0 \cdot 10 \\
0 \cdot 18 \\
0 \cdot 20 \\
0 \cdot 15 \\
0 \cdot 16\end{array}$ & $37 \cdot 9$ & $0 \cdot 17$ & $\begin{array}{l}3 \\
4 \\
3 \cdot 5 \\
2 \\
3 \\
3 \cdot 5 \\
-2 \\
-1 \\
2 \cdot 5\end{array}$ \\
\hline $\begin{array}{c}\text { Chrome } \\
\text { manganese } \\
\text { steel }\end{array}$ & $\begin{array}{l}\text { No. } 10 \\
\text { No. } 11 \\
\text { No. } 12 \\
\text { No. } 13 \\
\text { No. } 14 \\
\text { No. } 15\end{array}$ & $\begin{array}{l}37 \cdot 9 \\
36 \cdot 7 \\
40 \cdot 2 \\
41 \cdot 0 \\
38 \cdot 6 \\
38 \cdot 4\end{array}$ & $\begin{array}{l}0 \cdot 14 \\
0 \cdot 14 \\
0 \cdot 14 \\
0 \cdot 13 \\
0 \cdot 14 \\
0 \cdot 14\end{array}$ & $38 \cdot 8$ & $0 \cdot 14$ & $\begin{array}{l}5 \cdot 5 \\
5 \cdot 5 \\
3 \\
3 \\
3 \cdot 5 \\
4 .\end{array}$ \\
\hline $\begin{array}{l}\text { Ordinary high } \\
\text { manganese } \\
\text { steel } \\
\text { (high silicon) }\end{array}$ & $\begin{array}{l}\text { No. } 16 \\
\text { No. } 17 \\
\text { No. } 18\end{array}$ & $\begin{array}{l}39 \cdot 4 \\
41 \cdot 2 \\
37 \cdot 1\end{array}$ & $\begin{array}{l}0 \cdot 13 \\
0 \cdot 11 \\
0 \cdot 15\end{array}$ & $39 \cdot 2$ & $0 \cdot 13$ & $\begin{array}{l}5 \\
3 \\
2\end{array}$ \\
\hline $\begin{array}{c}\text { Specially } \\
\text { manufactured } \\
\text { high manga- } \\
\text { nese steel }\end{array}$ & $\begin{array}{l}\text { No. } 19 \\
\text { No. } 20 \\
\text { No. } 21 \\
\text { No. } 22 \\
\text { No. } 23 \\
\text { No. } 24 \\
\text { No. } 25 \\
\text { No. } 26 \\
\text { No. } 27\end{array}$ & $\begin{array}{l}46 \cdot 5 \\
21 \cdot 0 \\
21 \cdot 5 \\
61 \cdot 0 \\
45 \cdot 6 \\
43 \cdot 4 \\
50 \cdot 6 \\
32.6 \\
42 \cdot 0\end{array}$ & $\begin{array}{l}0.06 \\
0.49 \\
0.28 \\
0.08 \\
0.08 \\
0.10 \\
0.03 \\
0.26 \\
0.12\end{array}$ & $40 \cdot 5$ & $0 \cdot 15$ & $\begin{array}{l}2 \cdot 5 \\
2 \\
3 \\
2 \\
3 \cdot 5 \\
4 \\
3 \\
5 \\
5\end{array}$ \\
\hline
\end{tabular}

著ではなかった)，ショアー硬さでみれば初期硬さは 普通高マンガン鋼, 特殊溶解高マンガン鋼, 普通高マ ソガン鋼(高珪素)，クロームマンガン鋼の順に高くな り，硬さ上年率はこの順に少なくなっているようであ った。

\section{7.あとがき}

前報に引続いて, チューブミル型式による摩耗試験 機を用い各種高マンガン鋼のとくに摩耗初期における 耐摩耗特性を検討した結果，

（1）普通高マンガン鋼の熱処理による耐摩耗特性 の变化は水焼入れ(水じん)した後, $250^{\circ} \mathrm{C}$ に焼戻しし たものは水焼入れのままのものに比べてやや向上する ようであるが大差はなかったが， $650^{\circ} \mathrm{C}$ のように筧戻 温度をあげると特性は悪くなった。

（2）普通高マンガン鋼に珪素量を増加すれば耐摩 耗性に悪い影響を及ぼすことがわかった。

（3）クローム添加も同様に耐摩耗性に良好な結果

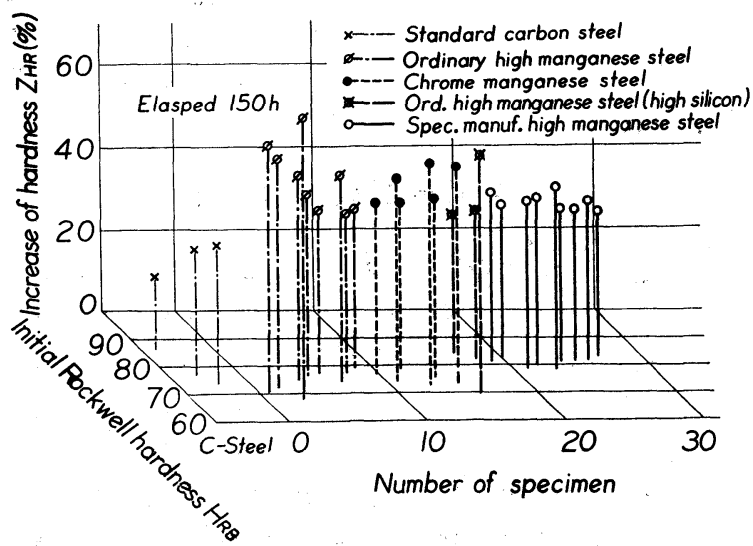

Fig. 10 The relation between the increase of hardness $Z_{H R}$ and the initial Rockwell hardness $H_{R B}$ in each specimen

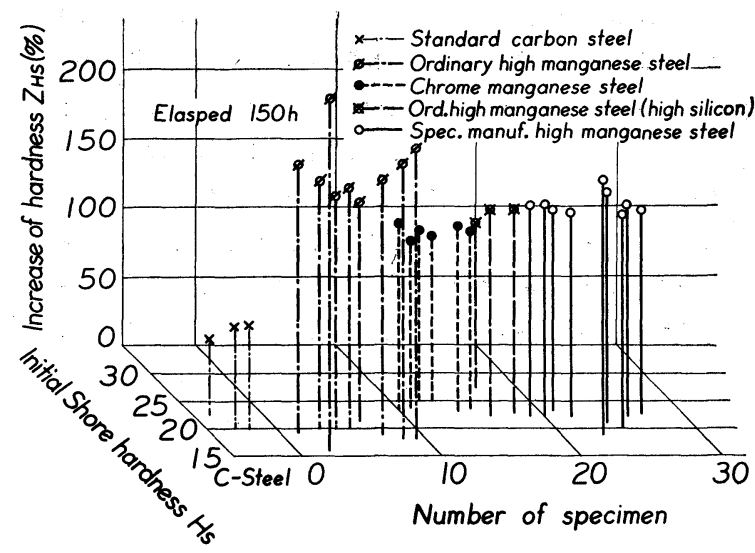

Fig. 11 The relation between the increase of hardness $Z_{H S}$ and the initial Shore hardness $H_{S}$ in each specimen 
を与えないことがわかった：

（4）特殊溶解処理を施したものは普通高マンガン 鋼に比べて，その化学的成分はほとんど大差ないにも かかわらず耐摩耗性はすぐれた特性を示した.

（5）オーステナイト粒度の粗粒のものが細粒のも のに比べ耐摩耗性が劣るという前報の結果はこの場合 も適用でさた。

（6）摩耗時間と摩耗量の関係は実験的に（1)式が 成立し, 式中の定数は各試料群においてそれぞれほぼ 等しい値をとることがわかった。

（7）また，摩耗時間と硬さの関係も（2)式が成立
し，式中の定数はそれぞれ試料によってほぼ等しい值 を取ったが，時間の経過につれて硬さの上升が炭素鋼 に比べてはなはだいちじるしいことは前報の結果と一 致した。

本研究の実施は日本鋳造株式会社川崎工場の御援助 によったことを付記する。

\section{参考文 献}

1) 八木, 材料試験, 8, 68, 423 (昭 34 )

2) 中山, 財満, 材料試験, 5, 37, 595 (昭31)

3) 特許出願中 (日本鋳造株式会社) そつき詳細は省略する

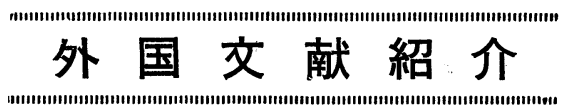

\section{材料試験法および試験機}

偏光塑性学に関する研究 (Studies in Photoplasticity) M.M. Frocht and R.A. Thomson, Proceedings of the Third U.S. National Congress of Applied Mechanics (1958), pp. 533-540, 図11, 表 なし

セルロイド模型を使放て平面断塑性応力状態の偏光 実験に関する基礎的問題が検討されている. 塑性状態 における応力は, その荷重履歴により影響されるよう な荷重の減少ないし除去がおこるような問題は取り报 われていない，実験法は非直線的な Stress-optic 法則 と等傾線の測定による。セルロイドの Birefringence $(n)$ はいっぱんに応力 $(\sigma)$ とひずみ $(\varepsilon)$ に関係するが， ひずみ $(\varepsilon)$ は応力 $(\sigma)$ と実験における時間 $(t)$ によると してひずみ $(\varepsilon)$ を消去できる，さらに Birefringence $(n)$ に及ぼす時間 $(t)$ の影響はクリープ曲線の充分時間 経過した值をとるとすると無視できるとして Stressoptic 法則を得られる. 偏光塑性実験の実験 Prototype への応用性に関しては両材料の (i) 応力ーひずみ
曲線, (ii)降伏条件, (iii)塑性域におけるポアソン比 ( が同じでなければならない。セルロイドの $\nu=0 \cdot 493$, (i)および (ii)の条件はアルミニウムに類似する。七ル ロイドの Birefringence $(n)$ および応力ーひずみ曲線は 温度および相対湿度に影響されるから，できるだけ一 定に保たれた。しかしながら，この条件を变えてセル ロイドの応力ーひずみ曲線を変化せしめると，セルロ イド模型による偏光塑性実験が新しい応力ーひずみ曲 線をもった材料一応用しうる。一円孔を有する平板や ノッチ，およびフィレットのある平板における応力集 中係数および一円孔を中心に有する平板の対称軸に沿 う応力分布が偏光塑性的に実験された. 前者の実験結 果はひずみ測定法による応力集中係数の計算と比較し てよく一致している, 後者の実験結果は RambergOsgood の方程式を使って応力ーひずみ曲線を無元的 に書さ変え Rayleigh rity の方法と関連した数値計算 で得た “correction stress”を理論解析塑性応力と比 較されて, 塑性変形があまり大きくない場合以外はか なりよく一致している.

（伊藤勝彦） 